\title{
Knowledge and attitudes of Subcarpathian Province's inhabitants towards organ transplantation
}

\author{
Wiedza i stosunek mieszkańców Podkarpacia wobec transplantacji narządów
}

\section{Małgorzata Moskal-Szybka, Justyna Borek}

Zakład Pielęgniarstwa, Instytut Zdrowia i Gospodarki, Państwowa Wyższa Szkoła Zawodowa im. Stanisława Pigonia w Krośnie/ Department of Nursing, Institute of Health and Economy, State Higher Vocational School in Krosno

\author{
CORRESPONDING AUTHOR/AUTOR DO KORESPONDENCJ: \\ Małgorzata Moskal-Szybka \\ Zakład Pielęgniarstwa, Instytut Zdrowia i Gospodarki, \\ Państwowa Wyższa Szkoła Zawodowa im. Stanisława Pigonia w Krośnie \\ Hallera St. 10/27, 38-400 Krosno \\ e-mail:mg.moskal@wp.pl
}

STRESZCZENIE

Słowa kluczowe:

ABSTRACT

\section{WIEDZA I STOSUNEK MIESZKAÑ CÓW PODKARPACIA WOBEC TRANSPLANTACJI NARZĄDÓW}

Wstęp. Transplantacja (z łac. transplantare - szczepić i plantare - sadzić) - inaczej przeszczep narządów, to bezpieczna, skuteczna i czasem jedyna metoda leczenia, pozwalająca na uratowanie ludzi ze skrajną niewydolnością narządów (serca, wątroby, płuc, nerek, trzustki). Polega na wymianie chorego narządu lub tkanek na nowe, pochodzące od innego człowieka. To szczególny rodzaj leczenia, wymagający akceptacji społecznej. Niezależnie od wysiłków podejmowanych przez polskie środowisko transplantacyjne, niski poziom świadomości społecznej i brak dostatecznej wiedzy na temat dawstwa narządów, stanowi wciąż istotną barierę dla rozwoju transplantacji w Polsce [1].

Cel pracy. Poznanie stanu wiedzy i stosunku mieszkańców Podkarpacia wobec transplantacji narządów.

Materiał i metody. Badania ankietowe przeprowadzono w 2018 roku z udziałem 187 mieszkańców miast i wsi województwa podkarpackiego, z wykształceniem innym niż medyczne. Badania przeprowadzono metodą sondażu diagnostycznego z zastosowaniem techniki ankiety. Narzędziem badawczym był autorski kwestionariusz ankiety składający się w większości z pytań jednokrotnego wyboru. Pytania zamieszczone w kwestionariuszu miały charakter pytań zamkniętych.

Wyniki i wnioski. Wiedza ankietowanych w zdecydowanej większości (u 56,9\% badanych z miasta oraz 57,4\% ze wsi) kształtowała się na poziomie umiarkowanym. Mniej badanych prezentowało wiedzę na poziomie wysokim: $34,7 \%$ z miasta oraz 31,3\% ze wsi. Wiedzą niską wykazało się 8,3\% respondentów z miasta oraz 11,3\% ze wsi. Nie odnotowano istotnego zróżnicowania poziomu wiedzy na temat transplantacji narządów ze względu na miejsce zamieszkania. Badania prezentowane w niniejszej pracy wskazują na niewystarczającą wiedzę mieszkańców na temat transplantacji. Respondenci w większości wykazują chęć oddania narządów w razie zaistniałej potrzeby. Zarówno badania prezentowane w niniejszej pracy, jak i opracowania innych autorów wskazują na potrzebę edukacji społeczeństwa, aby przyczynić się do pełnej akceptacji medycyny transplantacyjnej.

transplantacja, poziom wiedzy, postawa wobec transplantacji

KNOWLEDGE AND ATTITUDES OF SUBCARPATHIAN PROVINCESS INHABITANTS TOWARDS ORGAN TRANSPLANTATION Introduction. Transplantation (from Latin transplantare - transplant and plantare - plant), also called organ transplantation, is a safe, effective, and in some cases the only available treatment method giving hope for recovery for patients with end-stage organ failure (such as failure of heart, liver, lungs, kidneys, pancreas). It involves replacement of a diseased organ or tissue with healthy one obtained from another person. It is a specific treatment that requires social acceptance. Despite the efforts being made by the Polish transplantation community, low public awareness and lack of knowledge on organ donation are still significant barriers to the development of transplantation program in Poland [1].

Objective. Recognition of knowledge and attitudes of Subcarpathian Province's inhabitants towards organ transplantation.

Material and methods. The survey conducted in 2018 included 187 inhabitants of urban and rural areas of the Subcarpathian Province with non-medical background. A method of diagnostic survey with a questionnaire was used. The research tool was a proprietary questionnaire containing mostly single-choice questions. The questions in the survey were closed-ended.

Results and conclusons. The level of knowledge of most respondents (56.9\% of the respondents from urban areas and $57.4 \%$ of the respondents from rural areas) was moderate. High level of knowledge was presented by fewer respondents: $34.7 \%$ of those from urban areas and $31.3 \%$ of those from rural areas. Low level of knowledge was reported by $8.3 \%$ and $11.3 \%$ of the respondents from urban and rural areas, respectively. No significant differences in knowledge of organ transplantation were seen between the respondents from urban and rural areas. The results of this research show insufficient knowledge concerning organ transplan- 
tation in the surveyed population. Most respondents declare their willingness to donate organs when needed. Both our research presented in this paper and reports by other authors suggest the need for educating the public in order to encourage broad social acceptance for transplant medicine.

Key words: $\quad$ transplantation, level of knowledge, attitudes towards transplantation

\section{INTRODUCTION}

Transplantology is a science dealing with transplantation of organs, tissues and cells and is one of the branches of clinical medicine. It is an effective method of saving human life and treating patients suffering from end-stage organ failure [2]. The factor hindering the performance of medical procedures, such as transplants, is insufficient number of diseased organ donations [3]. Despite the knowledge, experience and commitment of transplantation teams in Poland, we are still very far from the level of organ donation recorded in such countries as Spain, Great Britain, Austria, Germany or the Czech Republic [1]. Diseased organ donation is a method of treatment that is perceived by the society as a sensitive topic and therefore requires more awareness and acceptance [4]. It should also be pointed out that according to the law, each of us, every member of our society, is a potential donor. It turns out that the low level of public knowledge about organ donation and transplantation, as well as the presumed consent principle, mean that the society continues to fear organ donation, what results in an insufficient number of organs that could be transplanted to the recipients in need. Also, the lack of knowledge about the concept of brain death may be a factor behind limited organ donations and lead to associating transplantation even with organ trafficking [3]. However, there is no other way to obtain an organ for transplantation than from another human being - alive or deceased. From the moral standpoint as well as from the medical practice perspective, transplantation is possible only with the acceptance of the society, as some of society members become organ donors transplanted to others and together with organ recipients form the so-called new life cycle. In this context, social knowledge about transplantation and the attitude of the society towards transplantation are very important [5]. We may have different points of view, belong to different religions, but in these situations, knowledge and science are the key [6]. This situation can be remedied by educating the society which can change the existing state of affairs [3].

The Subcarpathian Voivodeship records the lowest number of organ donations in Poland, hence the study to get to know the level of knowledge and attitudes of its inhabitants towards organ transplantation and to answer the question whether insufficient knowledge and awareness of its residents is the behind the problem or whether the issue is more complex.

\section{AIM}

The aim of the study was to get to know the state of knowledge and to analyze the attitudes of inhabitants of cities and villages of the Subcarpathian Voivodeship to organ transplantation.

\section{MATERIALS AND METHODS}

The diagnostic survey questionnaire technique was used to carry out the research. The research was performed with the use of the author's original questionnaire in 2018. The questionnaire consisted of two parts: the first contained questions about the knowledge of transplantology and personal attitude to the issue, the second part of the questionnaire asked questions about independent variables such as age, sex, education, place of residence or professional activity and religion. The questions included in the questionnaire were closed questions, they were scored on a scale from 0 to 1 . The correct answer was given 1 point, wrong answer or no answer was scored 0 point. All the questions required choosing one answer, in total one could get 12 points as regards questions testing respondents' knowledge. The obtained results were classified using a fixed scale: from 0 to 5 points - low level of knowledge, 6-9 points - moderate level of knowledge, 10-12 points - comprehensive knowledge.

The study group consisted of 187 inhabitants of towns and villages of the Subcarpathian Voivodship with no medical education background. The respondents were informed about the purpose and conduct of the study. The respondents completed the questionnaire individually, after filling in the questionnaire, they returned it to the researcher. The research was carried out in accordance with the principles of the Helsinki Declaration. The statistical analysis was carried out using the SPSS program. All relationships are statistically significant when $\mathrm{p}<0.05$.

\section{RESULTS}

The study group consisted of 187 persons, including 72 city dwellers and 115 inhabitants of rural areas. A total of 126 women and 61 men took part in the survey.

The number of $10.2 \%$ of the respondents were in the 15-18 age group and $16.6 \%$ of respondents were in the 19-25 age group. Most of the respondents were in the 26-35 age group - they accounted for $20.3 \%$ of all the respondents. In the group of persons aged 36-45, there were $19.3 \%$ of the respondents, both from cities and from rural areas. The number of persons aged 46-55 years constituted $18.7 \%$ of all the respondents, and the age group 56-65accounted for $10.2 \%$ of the respondents. Respondents above 65 years of age accounted for $4.8 \%$ of all the surveyed persons. 
Education of the respondents ranged from primary to university education. When it comes to $5.9 \%$ of the respondents, they completed primary and secondary school education, while $19.8 \%$ of the respondents received vocational education. The most numerous group were persons with secondary education: $40.6 \%$ of the respondents. The number of $7.5 \%$ of the respondents held Bachelor's degree , 23.5\% Master's degree and 2.7\% professional title of engineer.

The professional activity of the respondents was as follows: the largest group of the respondents were professionals or semi-professionals performing office or administrative work $-36.9 \%$ of the respondents. A large group were also physical workers $-30.5 \%$. Students accounted for $15 \%$ of the respondents. Few respondents, accounting for a mere $10.2 \%$,were the retired or pensioners. The smallest group were the unemployed - they accounted for $7.5 \%$ of the respondents.

In the group of respondents, the majority were practicing believers - they accounted for $87.7 \%$ of the respondents, whereas non-practicing believers accounted for $9.1 \%$ of the respondents. Of all the respondents, $1.6 \%$ reported that they were atheists and 3 persons (1.6\%) described their religion as different.

The question about the definition of transplantation was correctly answered by $89.8 \%$ of the respondents. Respondents who responded that transplantation was the transfer of body organs after death accounted for $9.6 \%$. One person indicated that it was the sale of a person's own organs after death.

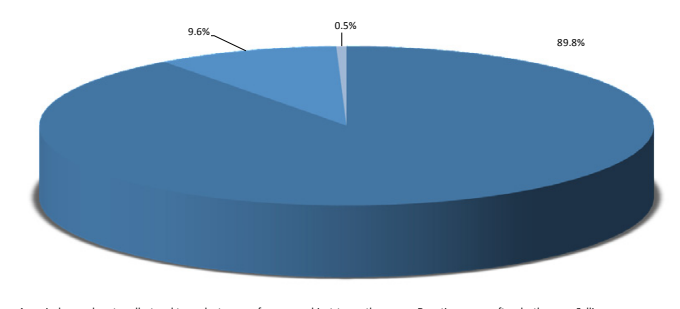

Fig 1. How do you understand transplantation?

More than half (59.9\%) of the respondents knew what were the most frequently transplanted organs in Poland.

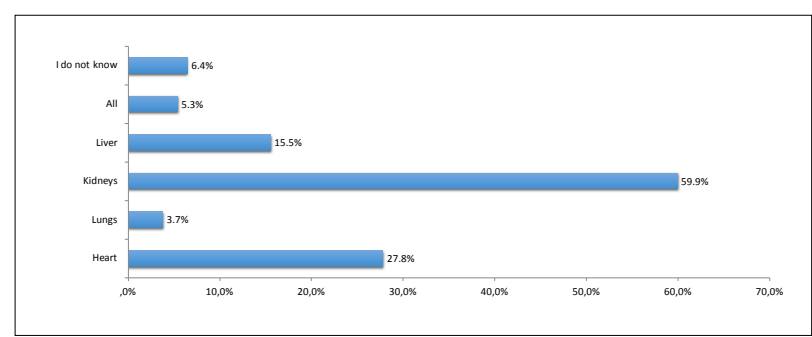

Fig 2. According to your knowledge, which organs are transplanted most frequently?

The overwhelming majority of the respondents, namely 95.7\%, when asked about the aim of organ transplantation said it was to extend patients' life. Three respondents gave a wrong answer saying the organ transplantation was for research purposes. A few persons, namely $3.2 \%$, did not know the answer to that question.

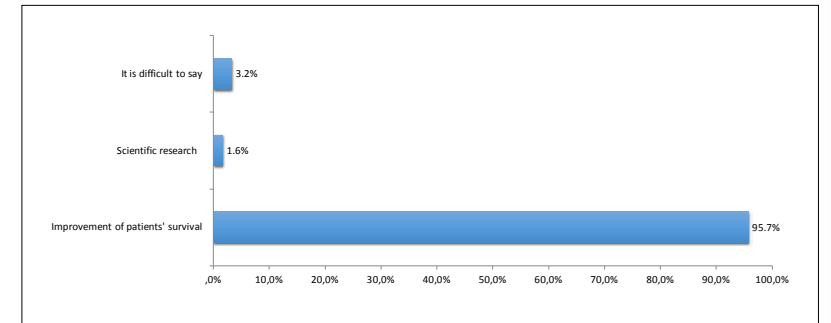

Fig 3. What is the purpose of transplanting organs?

The correct answer to the question about the necessary condition to be able to get an organ for transplantation, i.e. the patient's death certificate issued by specialists, was given by $23 \%$ of the surveyed persons. The majority of the respondents, $51.9 \%$ gave a wrong answer saying the living person's consent for organ donation was the necessary condition. Family's consent to organ donation was indicated by $32.1 \%$ of the respondents. Respondents who admitted that they did not know the answer to this question constituted $4.3 \%$

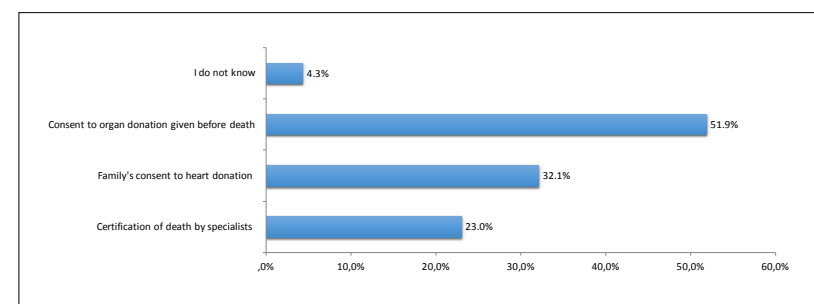

Fig 4. What precondition must be met to enable collection of organs for transplantation?

According to the majority of the respondents $-81.8 \%$, organs for transplantation may come from both the living and the dead donors. According to $8 \%$ of the respondents, organs for transplantation come only from the deceased, whereas $6.4 \%$ of respondents incorrectly indicated that organs for transplantation may come from the living donors only. When it comes to $3.7 \%$ of the respondents, they did not know the answer to that question.

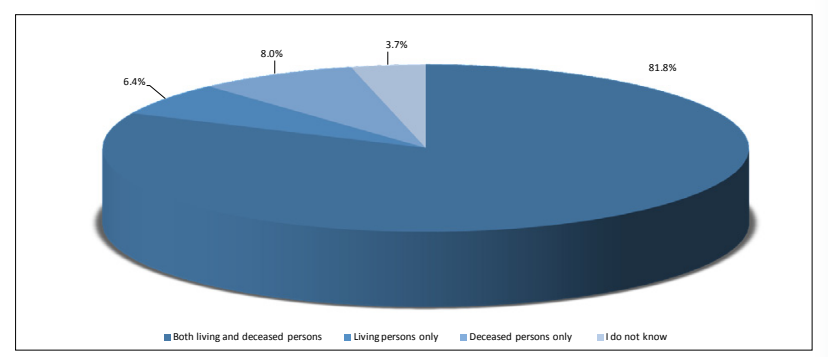

Fig 5. According to your knowledge, who can donate organs for transplantation?

The next stage of the study assessed the respondents' knowledge about the indications for kidney transplantation. The vast majority of the respondents $-80.7 \%$ rightly pointed to the end-stage renal failure. The number of $4.8 \%$ of the respondents pointed to chronic inflammation of the urinary tract, and $2.7 \%$ of the respondents considered urinary tract stones (urolithiasis) to be the correct answer. As many as $12.3 \%$ of the respondents did not know the answer. 


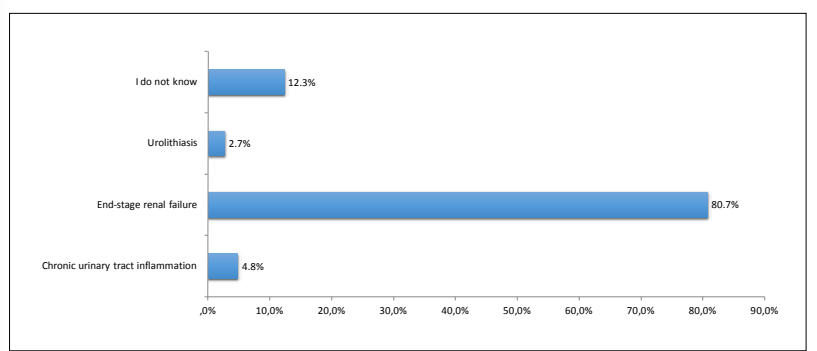

Fig 6. According to your knowledge, what are the indications for kidney transplantation?

When asked about „brain death” definition, the correct answer, i.e. irreversible cessation of the brain function, was given by $88.8 \%$ of the respondents. Only $3.2 \%$ responded incorrectly, saying that it was a reversible cessation of the brain function. When it comes to $8 \%$ of the respondents, they did not know this term.

The majority of the respondents $-71.7 \%$, knew the definition of the declaration of will saying that it is a person's informed written consent to having his/her organs removed after their death.

Erroneous answer was given by $16.6 \%$ of the respondents who said it was a legal document giving the consent to organ donation and transplantation, and $11.8 \%$ of the respondents considered that it was a document about the person's readiness to organ donation and transplantation, if necessary.

The question regarding the definition of implied consent posed a difficulty to the respondents. The correct definition, i.e. the absence of the living person's objection to organ donation and transplantation after his/her death, was given by $46.5 \%$ of the respondents. The remaining respondents considered that it was the consent of the donor's family to organ donation $(26.2 \%)$ and that it was the recipient's consent to organ donation and transplantation $(4.8 \%)$. As many as $22.5 \%$ of the respondents did not give any answer.

In response to the question whether the number of transplantations performed in Poland is sufficient in relation to the needs, the vast majority of respondents $-79.1 \%$ considered that it was insufficient. Only two of the respondents answered that the number of transplantations was sufficient, while $19.8 \%$ of the respondents did not know the answer.

The majority of the surveyed (78.6\%) demonstrated comprehensive knowledge indicating that the costs related to organ transplantation are covered by the National Health Fund. When it comes to $19.3 \%$ of the respondents, they did not know the answer, and a mere $2.7 \%$ indicated that the cost of the transplantation was covered by the organ recipient.

According to more than half of the respondents (59.4\%), the Church supports organ donation and transplantation. On the other hand, $12.3 \%$ of the surveyed were of the opinion that the Church is against organ donation and transplantation and $28.3 \%$ of respondents said that the Church did not express an opinion in this respect.

According to the adopted scoring used to assess the level of knowledge of the respondents, the knowledge about transplantology ranged from limited to extensive.
Knowledge of the respondents was generally moderate (6-9 points) - this level of knowledge was demonstrated by $57.2 \%$ of all the respondents. Extensive knowledge (10-12 points) was shown by $32.6 \%$ of the respondents. On the other hand, $10.2 \%$ of the respondents had limited knowledge (0-5 points) on the issue.

As regards questions about the attitude towards transplantation, the respondents' readiness to be a living donor in order to save close relative's life was reported by as many as $81.8 \%$ of the respondents. The „hesitating” group amounted to $12.8 \%$, while $5.3 \%$ would not consent to be a living organ donor.

Regarding the question about the respondents' attitude towards transplantation in the event of the brain death of their beloved ones and their readiness to be a living organ donor for transplantation, more than half of the respondents $-56.1 \%$ would consent to it if it saved someone's life. On the other hand, $35.3 \%$ of the respondents had doubts, while $8.6 \%$ would not give their consent.

The respondents were also asked if they had ever talked with their family about their attitude towards organ donation and transplantation. It turns out that more than half of the respondents $-56.7 \%$ have never talked about it to their relatives. The remaining respondents say that the family knows their standpoint in this regard.

\section{DISCUSSION}

Our study has shown that the respondents have some knowledge about general transplantology-related issues, such as the definition and the purpose of transplantation, the most frequently transplanted organs in Poland, the concept of brain death or indications for transplantation.

According to the respondents, kidneys are the organs which are the most often transplanted in Poland - such answer was given by $59.9 \%$ of the surveyed. The respondents also had some knowledge about the origin of organs for transplantation, as more than $80 \%$ of the surveyed persons answered that they came from both the deceased as well as living persons. Most of the respondents $-71.7 \%$ knew the definition of the „declaration of will' saying that it was a card expressing the person's informed written consent to removing his/her organs after death. Roman M. and Romankiewicz E. obtained very similar results. When asked about organs that can be transplanted, over $90 \%$ of the respondents indicated kidneys, over $80 \%$ of the respondents reported that organs for transplants come both from living donors and from the deceased. As many as $73 \%$ of city dwellers and $63 \%$ of rural areas inhabitants knew the definition of the "declaration of will' [7]. The studies found that half of the respondents gave incorrect answer to the question about the necessary condition to be met for transplantation. Only 23\% knew the answer. Similar results were obtained by Ścisło L., Partyka E., et al. The correct answer, i.e. the person's death certificate, was given by only $8 \%$ of the respondents [8].

The majority of the respondents (56.9\% of respondents from cities and $57.4 \%$ from rural areas) had a moderate level of knowledge. Fewer respondents demonstrated more comprehensive knowledge: $34.7 \%$ of city dwellers 
and $31.3 \%$ of inhabitants of rural areas. Only $8.3 \%$ of the respondents being city dwellers and $11.3 \%$ inhabitants of rural areas had limited knowledge. It is not surprising, given the education of the respondents, that the study found differences in the level of knowledge between persons holding a university degree and those with vocational education. Likewise, professionals or semi-professionals performing office or administrative work tend to demonstrate higher level of knowledge, while the unemployed tend to have limited knowledge. Similar results are presented in the literature. Użdalewicz and Mess argue that education has a significant impact on the level of knowledge about transplantation. The unemployed most often gave incorrect answers. An important difference was also noted between respondents who were Master's degree studies graduates and persons with vocational education [9].

It should be emphasized that an adequate level of knowledge is an extremely important factor affecting the readiness to volunteer to be an organ donor.

The author's own research as well as studies by other authors confirm that public awareness and acceptance of organ donation is steadily increasing. The research shows that $81.8 \%$ of the respondents declared their willingness to become living donors in order to save life of their beloved ones. When it comes to $56.1 \%$ of the surveyed, they would agree to the removal of organs from their beloved ones if they had suffered from brain death. It was observed that the oldest respondents had greater doubts about organ donation to their beloved ones in order to save their life.

According to the data from the Center for Public Opinion Research, $87 \%$ of the Polish society accept deceased organ donation for transplantation and consider it right, including $62 \%$ of people being clearly positive about it. Only a small group of the respondents $-7 \%$, does not approve this medical procedure. Also in the paper by Majchrowicz B. and Sadowska L., $80 \%$ of inhabitants of the Subcarpathian Voivodship accept the deceased organ donation. According to the studies by Szczepański S. and Pawlica B., the inhabitants of the Silesian Voivodship accept the deceased organ donation $-86 \%$ of the total number of the respondents [10].

National-wide surveys aimed to study the attitudes and opinions of various professional communities, such as students, doctors, nurses, and many regions of Poland, have been conducted for years. However, although the studied communities differ in the knowledge about transplantation, all respondents declare a positive attitude towards organ transplantation as a method of medical procedure. Various forms of popularizing the idea of transplantation, as well as the media seeking sensation, have contributed to spread the knowledge about transplantation among the Poles and have made them familiar with the emotions about the deceased organ donation. However, people's beliefs and views do not always translate into the expected behavior, because specific behaviors are determined by specific circumstances. Therefore in practice, the declared support of the idea of transplantation is not enough to accept organ donation after the death of the beloved one [11].
The Catholic church's support also strongly affects social attitudes in Poland towards transplantation [8]. All Christian religions fully support organ transplantation.

Imitating good solutions from abroad, engaging in educational activities of the society the medical communities and all entities affecting the number of potential organ donors, but also talking about the topic with family, friends, colleagues and working together, can considerably reduce obstacles that hinder the development of organ donation and transplantation in Poland and thus, save lives of many more patients awaiting a new organ, giving them a chance for a second life [1].

Danielewicz R., Director of ,Poltransplant' in 20112016, believes that local government units, hospitals, teachers and the clergy should be involved in raising awareness among the society. Everyone should work on a partnership basis, work in their areas to contribute to the full acceptance of transplant medicine.

Future generations need to be constantly reminded about transplantation. The society's education must be a never-ending process [6].

\section{CONCLUSIONS}

1. The inhabitants of the Subcarpathian Voivodship are familiar with the basic concepts of transplantology, however, their knowledge is limited and needs to be broadened.

2. Most respondents express a positive attitude towards organ donation and transplantation.

3. Over half of the surveyed communities have never talked with their family about the deceased organ donation.

4. The results of the studies indicate a continuous need to popularize transplantology, as well as to conduct a more thorough analysis of individual relationships and expand research on the level of knowledge and opinions on organ transplantation. 


\section{Wiedza i stosunek mieszkańców Podkarpacia wobec transplantacji narządów}

\section{WPROWADZENIE}

Transplantologia to nauka zajmująca się problematyką przeszczepiania narządów, tkanek i komórek, stanowi jeden z działów medycyny klinicznej. Jest skuteczną metodą ratowania życia ludzi i leczenia pacjentów cierpiących na schyłkową niewydolność narządu [2]. Czynnikiem limitującym wykonywanie zabiegów medycznych, jakimi są transplantacje, jest zbyt mała liczba narządów pobieranych od osób zmarłych [3]. Pomimo wiedzy, doświadczenia oraz zaangażowania zespołów transplantacyjnych w Polsce wciąż bardzo daleko nam do poziomu donacji narządów, jaki odnotowuje się w takich krajach jak Hiszpania, Wielka Brytania, Austria, Niemcy czy Czechy [1]. Pobieranie narządów od zmarłych jest metoda leczenia czuła w odbiorze społecznym, toteż wymaga szerokiej akceptacji [4]. Warto także jasno wskazać, że zgodnie z literą prawa - za enigmatycznym, potencjalnym dawcą stoi każdy z nas, każdy członek naszego społeczeństwa. Okazuje się, że niski poziom wiedzy społeczeństwa o dawstwie i transplantacji narządów oraz zasada zgody domniemanej sprawiają, że w społeczeństwie nadal utrzymują się obawy oraz uczucie strachu przed dawstwem narządów, czego konsekwencją jest niewystarczająca ilość organów, które można by transplantować potrzebującym ich biorcom. Również brak wiedzy dotyczącej koncepcji śmierci mózgu może mieć znaczenie dla ograniczonego dawstwa narządów oraz prowadzić do kojarzenia transplantacji choćby $\mathrm{z}$ handlem narządami [3]. Jednakże nie ma innej możliwości pozyskania narządu do przeszczepienia niż od drugiego człowieka - żywego lub zmarłego. W aspekcie zarówno moralnym, jak i praktyki medycznej przeszczepianie jest możliwe tylko przy akceptacji społeczeństwa, którego niektórzy członkowie stając się dawcami narządów przeszczepianych innym, wraz z biorcami tworzą tzw. nowy cykl życia. W tym kontekście bardzo ważne są zatem społeczna wiedza o transplantacji i postawa społeczeństwa wobec niej [5]. Można mieć różne poglądy, wyznawać różne religie, ale w tych sytuacjach oprócz przekonań podstawę stanowią wiedza i nauka [6]. Remedium na zaistniałą sytuację jest edukacja społeczeństwa, która może przyczynić się do zmiany zastanego stanu rzeczy [3].

W województwie podkarpackim odnotowuje się najniższą w kraju liczbę pobrań narządów, dlatego podjęto badania, których celem było poznanie poziomu wiedzy i postaw mieszkańców Podkarpacia wobec transplantacji narządów, by odpowiedzieć sobie na pytanie, czy wpływ na tę sytuację ma zbyt niska wiedza i świadomość mieszkańców czy problem jest bardziej złożony.

\section{CEL PRACY}

Celem badań było poznanie stanu wiedzy oraz analiza postaw mieszkańców miast i wsi Podkarpacia wobec transplantacji narządów.

\section{MATERIAŁ I METODY}

Do przeprowadzenia badań wykorzystano metodę sondażu diagnostycznego, z zastosowaniem techniki ankietowej. Badania przeprowadzono za pomocą kwestionariusza ankiety własnego opracowania w 2018 roku. Kwestionariusz ankiety składał się z dwóch części: pierwsza zawierała pytania, dotyczące wiedzy na temat transplantologii oraz stosunku osobistego do poruszanej problematyki, druga część kwestionariusza obejmowała pytania o zmienne niezależne takie jak: wiek, płeć, wykształcenie, miejsce zamieszkania czy aktywność zawodową i wyznanie. Pytania zamieszczone w kwestionariuszu miały charakter pytań zamkniętych, były punktowane w skali od 0 do 1 . Poprawna odpowiedź to 1 pkt., błędna odpowiedź lub jej nieudzielenie to 0 pkt. Wszystkie pytania wymagały wybrania jednej odpowiedzi, w sumie można było uzyskać 12 pkt. w zakresie pytań sprawdzających wiedzę. Uzyskane wyniki zostały sklasyfikowane według ustalonej skali: od 0-5pkt. niski poziom wiedzy, 6-9 pkt. umiarkowany, 10-12 pkt. wysoki poziom wiedzy.

Grupe badawczą stanowiło 187 mieszkańców miast i wsi województwa podkarpackiego, z wykształceniem innym niż medyczne. Poinformowano respondentów o celu i zasadach badań. Osoby badane wypełniały kwestionariusz indywidualnie, po wypełnieniu ankiety zwracali ją badającemu. Badania przeprowadzono zgodnie z zasadami Deklaracji Helsińskiej. Analiza statystyczna została przeprowadzona za pomoca programu SPSS a wszelkie związki są istotne z punktu widzenia statystycznego, gdy $\mathrm{p}<0,05$.

\section{WYNIKI}

Grupę badawczą stanowiło 187 osób, w tym 72 osoby z miasta i 115 ze wsi. W wypełnieniu ankiety uczestniczyło ogółem 126 kobiet i 61 mężczyzn.

W grupie wiekowej 15-18 lat było 10,2\% badanych. Od 19 do 25 lat miało 16,6\% ankietowanych. Najwięcej badanych osób mieściło się w przedziale wiekowym 26-35 lat - stanowili $20,3 \%$. W grupie respondentów w wieku 36-45 lat było 19,3\% osób, zarówno z miasta jak i ze wsi. Liczba osób w przedziale 46-55 lat stanowiła 18,7\%, a w przedziale wiekowym od 56 do 65 lat było 10,2\%. Respondentów powyżej 65 roku życia było 4,8\%.

Wykształcenie badanych kształtowało się od podstawowego po wyższe. Wykształcenie podstawowe i gimnazjalne posiadało 5,9\% badanych. Wykształcenie zawodowe podało $19,8 \%$ osób. Najliczniejszą grupę stanowiły osoby z wykształceniem średnim: 40,6\%. Wykształcenie wyższe licencjackie miało 7,5\% badanych. Tytuł magistra posiadało 23,5\% osób, a tytuł inżyniera 2,7\%.

Aktywność zawodowa badanych osób kształtowała się następująco: najliczniejszą grupę respondentów stanowiły 
osoby pracujące umysłowo, 36,9\% badanych. Liczną grupę stanowiły także osoby pracujące fizycznie - 30,5\%. W grupie ankietowanych było 15\% studentów/uczniów. Niewielu badanych, bo 10,2\% podało, iż pozostaje na emeryturze/rencie. W badaniu najmniejszą grupą byli bezrobotni $-7,5 \%$.

$\mathrm{W}$ grupie ankietowanych przewage stanowiły osoby wierzące praktykujące, bo $87,7 \%$ osób. Wierzący niepraktykujący stanowili 9,1\%. Spośród wszystkich badanych $1,6 \%$ podało, iż są ateistami a 3 osoby $(1,6 \%)$ określiły swoje wyznanie jako inne.

Na pytanie o definicję transplantacji prawidłowo odpowiedziało $89,8 \%$ badanych. Respondenci, którzy uznali, iż transplantacja to przekazywanie swoich narządów po śmierci stanowili 9,6\%. Jedna osoba zaznaczyła jako właściwą odpowiedź - sprzedawanie własnych organów po śmierci. Rycina 1.

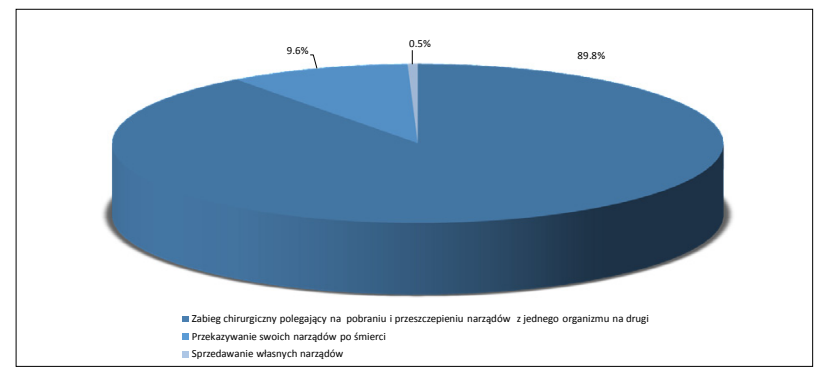

Ryc 1. Czym wg Pani/Pana jest transplantacja?

Wiedzę na temat najczęściej przeszczepianych organów w Polsce posiadała ponad połowa $(59,9 \%)$ ankietowanych.

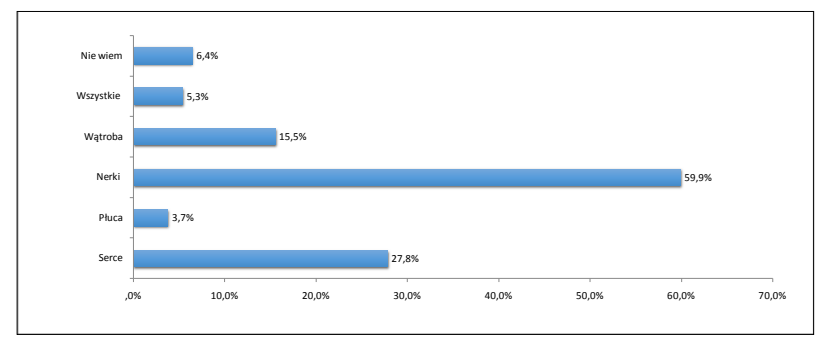

Ryc 2. Które narządy wg Pani/Pana są najczęściej przeszczepiane?

Zdecydowana większość respondentów, bo 95,7\% na pytanie o cel przeszczepiania narządów właściwie uznała, że jest to przedłużenie życia osobom chorym. Troje spośród badanych udzieliło błędnej odpowiedzi, wskazując, jako cel przeszczepiania narządów cel naukowo-badawczy. Kilka osób, tj. 3,2\% nie znało odpowiedzi na to pytanie.

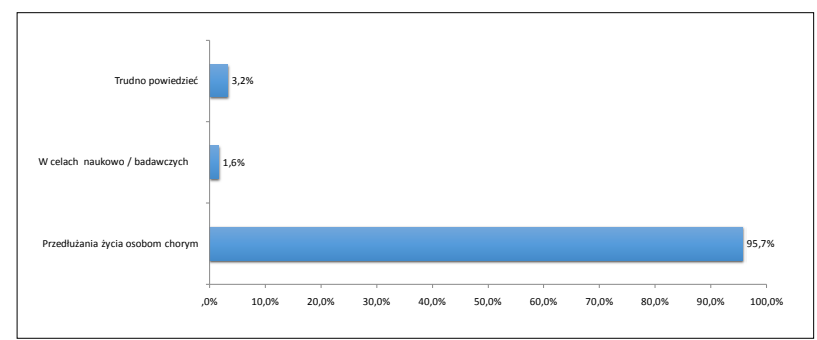

Ryc 3. W jakim celu wg Pani / Pana wykonuje się przeszczepy?
Prawidłowej odpowiedzi na pytanie o konieczny warunek, jaki należy spełnić, by można było pobrać narząd do przeszczepu, tj. orzeczenie zgonu pacjenta przez specjalistów, udzieliło 23\% osób. Większość respondentów, tj. $51,9 \%$ za prawidłową odpowiedź błędnie uznało wyrażenie zgody za życia na pobranie narządów. Odpowiedź dotyczącą wyrażenia zgody rodziny na pobranie wskazało $32,1 \%$ badanych. Ankietowani, którzy przyznali, iż nie znają odpowiedzi na to pytanie stanowili $4,3 \%$.

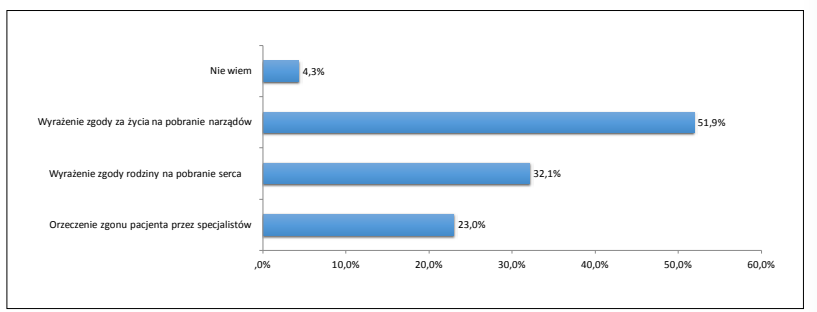

Ryc 4. Jaki warunek wg Pani/Pana musi zostać spełniony by można było pobrać narząd do przeszczepu?

Narządy do przeszczepu według większości respondentów $-81,8 \%$ mogą pochodzić zarówno od osób żywych jak i zmarłych. Według $8 \%$ ankietowanych tylko od osób zmarłych, a 6,4\% badanych błędnie wskazało, że narządy do przeszczepu mogą pochodzić tylko od osób żywych. Odpowiedzi na to pytanie nie znało 3,7\% badanych.

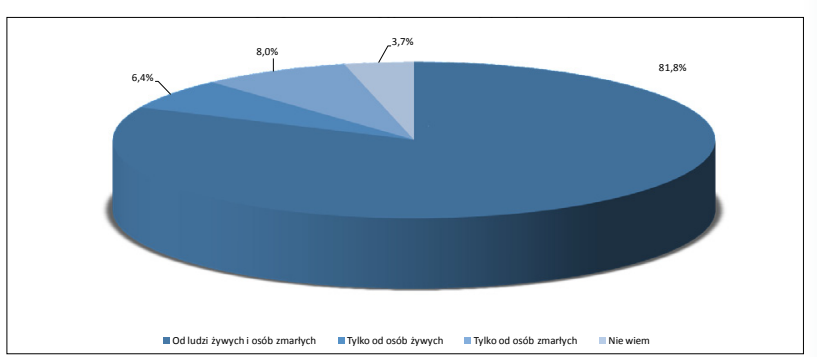

Ryc 5. Od kogo wg Pani /Pana mogą pochodzić narządy do przeszczepu?

W kolejnym etapie ocenie została poddana wiedza respondentów na temat wskazań do przeszczepienia nerki. Zdecydowana większość ankietowanych - 80,7 \% słusznie wskazała na schyłkową niewydolność nerek. 4,8\% badanych wskazało na przewlekłe stany zapalne dróg moczowych, a 2,7\% osób za poprawną odpowiedź uznało kamicę dróg moczowych. Odpowiedzi nie znało 12,3\% badanych.

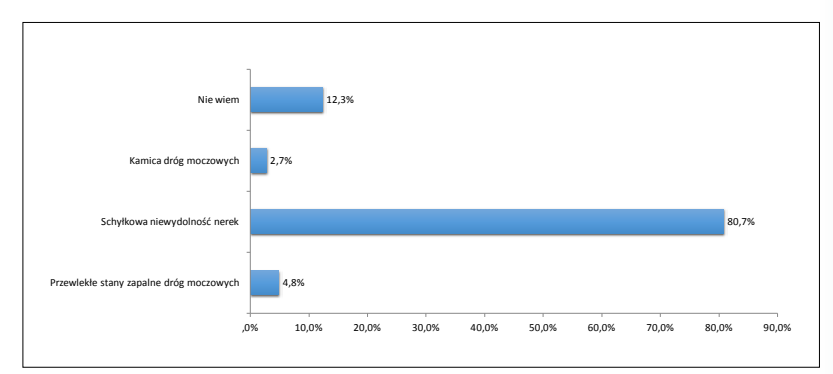

Ryc 6. Jakie wg Pani / Pana są wskazania do przeszczepu nerki? 
Na pytanie o znajomość terminologii „śmierć mózgu” prawidłowej odpowiedzi, tj. nieodwracalne ustanie pracy mózgu udzieliło $88,8 \%$ ankietowanych. Błędnie odpowiedziało jedynie 3,2\% osób uznając, że jest to odwracalne ustanie pracy mózgu. Pojęcia tego nie znało 8\% badanych.

Większość ankietowanych - 71,7\% wykazała się prawidłową znajomością definicji oświadczenia woli podając, iż jest to karta wyrażająca świadomą pisemną zgodę człowieka na pobranie jego narządów po jego śmierci. Błędnie odpowiedziało $16,6 \%$ wskazując, iż jest to dokument prawny decydujący o zgodzie na pobranie i przeszczepienie narządów, a 11,8\% badanych uznało, iż jest to dokument o gotowości do transplantacji w razie takiej potrzeby.

Pytanie dotyczące definicji zgody domniemanej stanowiło trudność dla respondentów. Prawidłową definicję, czyli nie wyrażenie sprzeciwu za życia na pobranie narządów do przeszczepu po śmierci, podało 46,5\% osób. Pozostali respondenci uznali, iż jest to zgoda rodziny na pobranie narządów do przeszczepu $(26,2 \%)$ oraz, że jest to zgoda biorcy na wykonanie u niej przeszczepu $(4,8 \%)$. Odpowiedzi nie wiem udzieliło 22,5\% ankietowanych.

W odpowiedzi na pytanie: czy liczba wykonywanych przeszczepów w Polsce jest wystarczająca w stosunku do potrzeb, zdecydowana większość badanych -79,1\% uznała, że nie jest wystarczająca. Tylko dwie osoby spośród badanych udzieliły odpowiedzi: tak jest wystarczająca, natomiast 19,8\% respondentów nie znało odpowiedzi.

Ankietowani w większości (78,6\%) wykazali się znajomością wiedzy wskazując, iż koszty związane z przeszczepianiem narządów pokrywa Narodowy Fundusz Zdrowia. Odpowiedzi nie znało 19,3\% badanych, a zaledwie 2,7\% wskazało, że koszty przeszczepu pokrywa biorca.

Według ponad połowy badanych $(59,4 \%)$ Kościół popiera ofiarowanie narządów i przeszczepy organów. Natomiast 12,3\% osób uważa, iż Kościól jest przeciwko transplantacji, a 28,3\% respondentów podało, że Kościół nie wyraził zdania na ten temat.

Zgodnie $\mathrm{z}$ ustaloną punktacją, mającą na celu ocenę poziomu wiedzy ankietowanych, wiedza na temat transplantologii kształtowała się od niskiej po wysoką. Wiedza ankietowanych, w zdecydowanej większości kształtowała się na poziomie umiarkowanym (6-9 punktów), który prezentowało $57,2 \%$ ogółu badanych. Wiedzę na poziomie wysokim (10-12 punktów) osiągnęło 32,6 \% respondentów. Natomiast wiedzę w stopniu niskim (0-5 pkt.) prezentowało $10,2 \%$ badanych.

W kontekście pytań o stosunek wobec transplantacji, gotowość ankietowanych do oddania swoich narządów za życia, celem ratowania osoby bliskiej, podało aż $81,8 \%$ badanych. W grupie osób „wahających się” jest 12,8\%, natomiast $5,3 \%$ nie wyraziło by zgody.

Spośród odpowiedzi na pytanie o ustosunkowanie się ankietowanych wobec transplantacji w przypadku orzeczenia śmierci mózgu ich bliskiej osoby i możliwości pobrania od niej narządów do przeszczepu, ponad połowa respondentów - 56,1\% osób zgodziłaby się, gdyby uratowało to czyjeś życie. Kolejno 35,3\% ankietowanych ma wątpliwości, natomiast $8,6 \%$ nie udzieliło by zgody.

Ankietowanym zadano również pytanie czy kiedykolwiek rozmawiali z rodziną na temat swojego stosunku wobec przeszczepów. Okazuje się, iż ponad połowa badanych - 56,7\% nigdy nie rozmawiała na ten temat $z$ bliskimi. Pozostali podają, iż rodzina wie jakie jest ich stanowisko w tym temacie.

\section{DYSKUSJA}

W badaniach własnych wykazano, iż ankietowani wykazują wiedzę na temat ogólnych zagadnień transplantologii, takich jak wiedza na temat definicji i celu transplantacji, narządów najczęściej przeszczepianych w Polsce, pojęcia śmierci mózgu czy wskazań do przeszczepu.

Wg respondentów narządy najczęściej przeszczepiane w Polsce to nerki i tak wskazało 59,9\% osób. Badani wykazali się też słuszną wiedzą na temat pochodzenia narządów do przeszczepu, gdyż ponad $80 \%$ osób odpowiedziało, że pochodzą od osób zmarłych jak i ludzi żywych. Większość ankietowanych -71,7\% wykazała się prawidłową znajomością definicji 'oświadczenia woli' podając, iż jest to karta wyrażająca świadomą pisemną zgodę człowieka na pobranie jego narządów po jego śmierci. Bardzo podobne wyniki badań uzyskały Roman M. i Romankiewicz E.: na pytanie o narządy, które można przeszczepić, ponad $90 \%$ badanych wskazało nerki, ponad $80 \%$ ankietowanych podało iż narządy do przeszczepów pochodzą od ludzi żywych i osób zmarłych. Znajomością definicji 'oświadczenie woli' wykazało się 73\% osób z miasta i 63\% ze wsi [7]. W badaniach zaobserwowano, że połowa ankietowanych błędnie odpowiedziała na pytanie o konieczny warunek jaki musi być spełniony do pobrania przeszczepu. Tylko 23\% udzieliło właściwej odpowiedzi. Podobne wyniki uzyskały Ścisło L., Partyka E. i współ., prawidłowej odpowiedzi, tj. orzeczenie zgonu pacjenta, udzieliło zaledwie $8 \%$ badanych [8].

Stan wiedzy ankietowanych w większości (u 56,9\% badanych z miasta oraz 57,4\% ze wsi) kształtował się na poziomie umiarkowanym. Mniej badanych prezentowało wiedzę na poziomie wysokim: $34,7 \% \mathrm{z}$ miasta oraz $31,3 \%$ ze wsi. Wiedzą niską wykazało się $8,3 \%$ respondentów miasta oraz $11,3 \%$ ze wsi. Nie jest zaskoczeniem, że biorąc pod uwagę wykształcenie badanych, różnicę w poziomie wiedzy, obserwuje się pomiędzy osobami z wykształceniem wyższym magisterskim a osobami z wykształceniem zawodowym, jak też, że osoby wykonujące pracę umysłową w większym stopniu odznaczają się wyższym poziomem wiedzy, natomiast osoby bezrobotne częściej charakteryzują się niższą wiedzą. Podobne wyniki podaje literatura. Użdalewicz i Mess piszą, iż wykształcenie ma znaczący wpływ na poziom wiedzy na temat transplantacji. Osoby bezrobotne najczęściej udzielały nieprawidłowych odpowiedzi. Istotną różnicę zauważono również między respondentami, którzy ukończyli studia magisterskie, a osobami z wykształceniem zawodowym [9].

Warto podkreślić, że adekwatny poziom wiedzy jest bezwzględnie istotnym czynnikiem wpływającym na gotowość ofiarowania własnych organów do przeszczepu.

Badania własne oraz innych autorów potwierdzają, że w społeczeństwie $\mathrm{z}$ biegiem lat wzrasta akceptacja wobec transplantacji narządów. $Z$ badań wynika, że 81,8\% respondentów podało gotowość do oddania swoich narządów 
za życia, celem ratowania osoby bliskiej. 56,1\% osób zgodziłaby się na pobranie narządów od osoby najbliższej w sytuacji orzeczenia u niej śmierci mózgu. Zaobserwowano, iż najstarsi badani mają większe wątpliwości co do ewentualnego oddania swojego narządu osobie bliskiej w celu ratowania życia.

Dane z Centrum Badania Opinii Społecznej wskazują, iż 87\% polskiego społeczeństwa akceptuje przeszczepianie narządów pobranych od osób zmarłych i uważa to za słuszne, w tym $62 \%$ osób potwierdziło to w sposób zdecydowany. Tylko niewielka grupa badanych $-7 \%$ - nieaprobuje tej metody leczenia. Także w pracy Majchrowicz B. i Sadowskiej L. mieszkańcy Podkarpacia w $80 \%$ akceptują pobieranie narządów od osób zmarłych. Według badań Szczepańskiego S. i Pawlicy B. mieszkańcy województwa śląskiego akceptują pobieranie narządów od osób zmarłych - 86\% ogółu badanych [10].

Prowadzone od lat ogólnopolskie sondaże służące badaniu postaw i opinii różnych środowisk- np. uczniów, studentów, lekarzy, pielęgniarek, $\mathrm{z}$ wielu regionów Polski pokazują, że chociaż badane środowiska różnią się wiedzą o transplantacji to jednak wszyscy respondenci deklarują pozytywne nastawienie wobec przeszczepiania narządów, jako metody leczenia. Różne formy popularyzacji idei przeszczepiania, a także media szukające sensacji, przyczyniły się do wzrostu wiedzy wśród Polaków o transplantacji i spowodowały oswojenie się z emocjami, które budzi pobieranie narządów od zmarłych. Jednakże przekonania ludzi i głoszone przez nich poglądy nie zawsze przekładają się na oczekiwane zachowania, ponieważ o tych zachowaniach decydują określone, swoiste okoliczności. Tak wiec w praktyce deklarowane poparcie idei transplantacji nie wystarcza do akceptacji pobrania narządów po śmierci bliskiej osoby [11].

Istotna dla formowania postaw społecznych w Polsce wobec transplantacji jest też znajomość w tej sprawie pozytywnego stanowiska kościoła katolickiego [8]. Wszystkie religie chrześcijańskie w pełni popierają przeszczepianie narządów.

Naśladując dobre rozwiązania z zagranicy, angażując się w działalność edukacyjną społeczeństwa, środowiska medycznego i wszystkich podmiotów, mających wpływ na ilość zgłaszanych potencjalnych dawców narządów, ale także rozmawiając na ten temat $\mathrm{z}$ rodziną, przyjaciółmi, znajomymi, współpracownikami, działając razem, możemy w znaczący sposób zredukować przeszkody, które utrudniają rozwój donacji narządów w Polsce i dzięki temu uratować znacznie więcej chorych, oczekujących na nowy organ, na drugie życie [1].

Danielewicz R., Dyrektor 'Poltransplantu” w latach 2011-2016, uważa, iż w edukację kierowaną do społeczeństwa powinny być zaangażowane władze samorządowe, dyrekcje szpitali, nauczyciele, duchowieństwo. Wszyscy powinni działać na zasadach partnerstwa, pracować na swoich obszarach, aby przyczynić się do pełnej akceptacji medycyny transplantacyjnej.

O transplantologii trzeba stale przypominać kolejnym pokoleniom. Proces edukacji społeczeństwa musi trwać nieprzerwanie [6].

\section{WNIOSKI}

1. Mieszkańcy Podkarpacia wykazują się znajomością podstawowych pojęć z zakresu transplantologii, jednakże wiedza jest niepełna i wymaga uzupełnień.

2. Większość respondentów wyraża pozytywny stosunek do transplantacji narządów.

3. Ponad połowa badanej społeczności nigdy nie rozmawiała $\mathrm{z}$ rodziną na temat przekazania swoich narządów po śmierci.

4. Wyniki podjętych badań wskazują na ciągłą potrzebę popularyzacji transplantologii, jak też przeprowadzenia bardziej wnikliwej analizy poszczególnych zależności i poszerzenia badań dotyczących poziomu wiedzy i opinii na temat przeszczepów narządów.

\section{REFERENCES/PIŚMIENNICTWO}

1. Król B, Zembala-John J. Transplantacja narządów. Aspekty medyczne, prawne i organizacyjne. Zabrze: Fundacja Śląskiego Centrum Chorób Serca w Zabrzu; 2013, s.6,8,9.

2. Wasak A. Transplantacje. Radom: Polskie Wyd. Encyklopedyczne; 2007, s.18, 21.

3. Woderska N. Wiedza i opinie młodzieży dotyczące dawstwa narządów do transplantacji. Aspekty edukacyjne. Poznań; 2018, s.10.

4. Czerwiński J, Danielewicz R. Prawo i organizacja przestrzeni transplantacyjnej. [w:] Czerwiński J, Małkowski P, red. Pielęgniarstwo transplantacyjne. Warszawa: Wyd. Ars Nova; 2014, s. 39.

5. Czerwiński J, Jakubowska-Winecka A, Woderska A, i wsp. Pobieranie narządów od zmarłych. [w:] Czerwiński J, Małkowski P, red. Pielęgniarstwo transplantacyjne. Warszawa: Wyd. Ars Nova; 2014,s. 86.

6. Sieradzka A. Tajemnice transplantacji. Warszawa: Wyd. PWN SA; 2017, s.33,155.

7. Roman M, Romankiewicz E. Analiza wiedzy mieszkańców miasta i wsi na temat transplantacji. [w:] Majchrzak-Kłokocka E, Seliga R, red. Wybrane problemy organizacji i zarządzania w pielęgniarstwie. Pielęgniarstwo bez granic. Przedsiębiorczość i Zarządzanie. Łódź: Wyd. SAN; 2013,tom.XIV, zeszyt.10, częśćll, s. $433-445$.

8. Ścisło L, Partyka E, Walewska E, i wsp. Postawy i wiedza mieszkańców wsi i miast na temat transplantacji narządów. Hygeia Public Health. 2013, 48(1): 40-45.

9. Użdalewicz Z, Mess E. Czynniki wpływające na stan wiedzy społeczeństwa na temat transplantacji narządów. Problemy Pielęgniarstwa 2016; 24 (3-4): 232-237.

10. Humańska M, Dudek KM. Analiza postaw młodzieży wobec transplantacji narządów. http://dx.doi.org/10.21784/Iw P.2017.004, z dn. 12.09.2018r.

11. Jakubowska-Winecka A. Socjologiczne i psychologiczne aspekty pobierania i przeszczepiani narządów od zmarłych. [w:] Czerwiński J, Małkowski P, red. Pielęgniarstwo transplantacyjne. Warszawa: Wyd. Ars Nova; 2014, s. $42-43$.

Manuscript received/Praca zgłoszona do czasopisma: 16.04.2019

Manuscript accepted/Praca zaakceptowana do druku: 07.06.2019

Translation/Tłumaczenie: Katarzyna Welman 